\title{
RISK FACTORS OF PRIMARY LUNG CANCER AMONG FEMALES
}

\author{
Nancy Glory Davidson ${ }^{1}$
}

${ }_{1}^{1}$ Associate Professor, Department of Respiratory Medicine, Government Stanley Medical College, Chennai, Tamilnadu, India.

\section{ABSTRACT}

\section{BACKGROUND}

Lung cancer is fast emerging to be a leading cause of cancer mortality, both in developing and developed countries alike. Despite the fact that tobacco smoke is a predominant cause, its increasing incidences among women, especially from non-smoking population puts forth a huge challenge for health care providers.

It is therefore essential to evaluate the risk factors and this study was done among female patients who were diagnosed with primary lung cancer.

\section{MATERIALS AND METHODS}

This cross-sectional study was carried out for a period of 15 months among the female outpatients who were suspected of lung cancer and confirmed as any one of the types of primary lung cancers by histopathological diagnosis. The history and clinical features of the patients were recorded and data regarding certain exposures were documented.

\section{RESULTS}

The mean age of the study participants was 49 years. Breathlessness was present in $51.6 \%$ of the participants, while cough and chest pain were present in 13 patients (41.9\%) each. Exposure to ETS (Environmental Tobacco Smoke) was present in 14 patients (45.2\%). Genetic predisposition for malignancy was present in 5 patients $(16.1 \%)$ in this study.

\section{CONCLUSION}

Occupational pollutants and Radiation have an additive effect in the background of genetic predisposition in the causation of Lung Cancer in females. Therefore, smoking tobacco is no longer considered as a single most important risk factor, considering the magnitude of the disease among females in a non-smoking population.

\section{KEY WORDS}

Adenocarcinoma, Environmental Tobacco Smoke, Haemoptysis, Lung Cancer, Smoking.

HOW TO CITE THIS ARTICLE: Davidson NG. Risk factors of primary lung cancer among females. J. Evolution Med. Dent. Sci. 2018;7(42):4519-4522, DOI: $10.14260 /$ jemds/2018/1008

\section{BACKGROUND}

Lung cancer is a major health problem worldwide. The incidence and mortality of lung cancer has been increasing steadily since $1930 \mathrm{~s}$, owing to increase in tobacco consumption. In 2008 there were over six million new cases of lung cancer all over the world, which was $12.7 \%$ of all the cancer incidences.[1] It is the leading cause of cancer mortality in most of the countries in the world. It remains the most lethal form of cancer in men and has now surpassed breast cancer in women. In the USA the lifetime probability of developing lung cancer for men is 1 in 13 , while the same for women is 1 in 16.[2] As far as the mortality is concerned, lung cancer accounts for more deaths than any other cancer for both men and women. However, the mortality due to lung cancer in women was reported to be 38.5 per $100,000 .{ }^{[3]}$

According to GLOBOCAN 2012 report, there were 16,547 new cases of lung cancer among Indian females with $91 \%$ mortality. Lung cancer constitutes $6.8 \%$ of all carcinomas in India.[4] Lung cancer is second only to breast cancer in females. Several studies have established the role of smoking in the causation of lung cancer.

'Financial or Other Competing Interest': None.

Submission 06-09-2018, Peer Review 01-10-2018,

Acceptance 06-10-2018, Published 15-10-2018.

Corresponding Author:

Dr. Nancy Glory Davidson,

No. 82/4, Vadivel Main Street,

Perambur, Chennai-600011, Tamilnadu, India.

E-mail: nancy_ranjit@yahoo.co.in

DOI: $10.14260 /$ jemds $/ 2018 / 1008$
Moreover, urbanisation and industrialisation have also increased in the recent past, which could have increased the incidence of environmental risk factors, thereby attributing to the increase in the incidence of lung cancer.

Complex factors like genetic predisposition, environmental exposure and lifestyle habits combine over a lifetime to initiate and promote tumour growth in the lung. The prognosis of lung cancer remains poor, in spite of advances in imaging techniques and treatment modalities with a five-year survival of $14 \%$ in early stages and less than $5 \%$ in locally advanced stages. [5] Unfortunately, only $20-30 \%$ of patients present with an operable disease, while most of the patients present in an advanced stage III and IV. The main reason for late presentation in our country is the poor health awareness, delayed recognition and the poor referral of patients to the specialised centres. Moreover, there are limited options for screening available in India, owing to time and cost. It has been indeed a challenge to reach out to the people and identify the population at risk. This prompts the need for evaluating the risk factors, so that these risk factors provide a base at the entry point to undertake radiological screening at the health facility.

Objectives- To evaluate the risk factors of primary lung cancer among females.

\section{MATERIALS AND METHODS}

Study Setting- This study was carried out as a cross-sectional study among the female patients attending the outpatient 
clinic of the Respiratory Medicine Department of our Government Hospital, Chennai. The duration of the study was for a period of 15 months.

\section{Study Population}

All the female patients who presented with clinical symptoms, suggestive of primary lung cancer during the study period were selected for the study. A histopathological diagnosis was made on these patients and all those participants confirmed to have primary lung cancer were taken up for this study. Males were excluded. Female patients with other respiratory symptoms who were negative for primary lung cancer by histopathology were excluded from the study.

\section{Sample Size and Sampling Technique}

The participants were selected by convenient sampling. A total of 31 females participated in this study.

\section{Ethical Approval and Informed Consent}

Approval from the Institutional Ethics Committee was obtained prior to the commencement of the study. Each participant was explained in detail about the study and informed consent was obtained prior to data collection.

\section{Data Collection}

The study protocol included a detailed history regarding the onset and progress of the disease, lifetime exposure to smoking, detailed occupational history, residence and exposure to indoor air pollution due to burning of organic fuels. A detailed history regarding malignancy in the firstdegree relatives of patients was also taken.

The complaints which were evaluated in detail included cough, sputum, haemoptysis, chest pain, dyspnoea, fever, weight loss, hoarseness of voice, dysphagia and symptoms suggestive of SVC obstruction, paraneoplastic syndromes and systemic metastasis. A detailed general and systemic examination was performed.

\section{Following Investigations helped in the Histopathological} Confirmation of the Diagnosis

1. Computerised tomography-guided needle biopsy.

2. Ultrasound-guided needle biopsy.

3. Endobronchial biopsy with fibreoptic bronchoscopy.

4. Excision biopsy of accessible peripheral lymph node.

\section{Data Analysis}

Data was entered and analysed using Microsoft Excel Spreadsheet 2010. The prevalence of risk factors was computed as percentage.

\section{RESULTS}

The following are the results of this cross-sectional study done on 31 female patients who were diagnosed with primary lung cancer. The age group of the participants ranged from 28 to 68 years. Majority of the participants belonged to 41 - 50 years. The age distribution of the study participants is given in Figure 1.

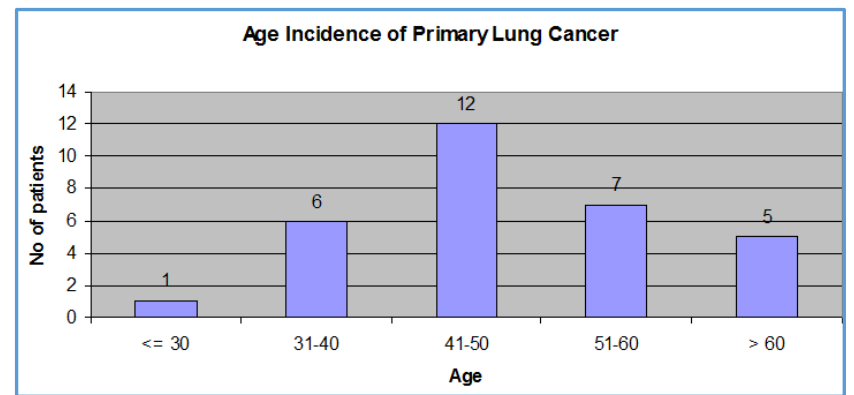

Figure 1. The Age distribution of the Study Participants

The particulars regarding the clinical presentation of primary lung cancer is given in Table 1 . The most common pulmonary symptoms were breathlessness, cough, chest pain and haemoptysis. Of this breathlessness was present in 16 patients $(51.6 \%)$, cough was present in 13 patients $(41.9 \%)$ followed by chest pain in 13 patients $(41.9 \%)$ and haemoptysis in 10 patients $(32.3 \%)$.

\begin{tabular}{|c|c|c|c|}
\hline Sl. No. & Symptoms & Frequency $\mathbf{N}=31$ & Percentage \\
\hline \multirow[t]{3}{*}{1} & Cough & & \\
\hline & Present & 13 & 41.9 \\
\hline & Absent & 18 & 58.1 \\
\hline \multirow[t]{3}{*}{2} & Chest Pain & & \\
\hline & Present & 13 & 41.9 \\
\hline & Absent & 18 & 58.1 \\
\hline \multirow[t]{3}{*}{3} & Haemoptysis & & \\
\hline & Present & 10 & 32.3 \\
\hline & Absent & 21 & 67.7 \\
\hline \multirow[t]{3}{*}{4} & Breathlessness & & \\
\hline & Present & 16 & 51.6 \\
\hline & Absent & 15 & 68.4 \\
\hline \multirow[t]{3}{*}{5} & Hoarseness of Voice & & \\
\hline & Present & 4 & 12.9 \\
\hline & Absent & 27 & 87.1 \\
\hline
\end{tabular}

The prevalence of risk factors among the study participants is given in Table 2. No patient in this study was an active smoker. But exposure to ETS (Environmental tobacco smoke) was present in 14 patients (45.2\%). About 12 patients $(38.7 \%)$ gave definite history of exposure to biomass fuels like cow dung cake and agricultural waste, wood and coal. Out of 31 patients, 1 patient (3.2\%) gave history of exposure to asbestos in the working place. About 2 patients $(6.4 \%)$ gave history of exposure to radiation. Genetic predisposition for malignancy was present in 5 patients (16.1\%) in this study.

\begin{tabular}{|c|c|c|c|}
\hline Sl. No. & Risk Factors & $\begin{array}{c}\text { Frequency } \\
\mathbf{N = 3 1}\end{array}$ & Percentage \\
\hline $\mathbf{1}$ & $\begin{array}{c}\text { Environmental } \\
\text { tobacco smoke }\end{array}$ & & \\
\hline & Present & 14 & 45.2 \\
\hline & Absent & 17 & 54.8 \\
\hline $\mathbf{2}$ & Indoor air pollution & & \\
\hline & Present & 12 & 38.7 \\
\hline & Absent & 19 & 61.3 \\
\hline $\mathbf{3}$ & $\begin{array}{c}\text { Occupational } \\
\text { exposure }\end{array}$ & & \\
\hline & Present & 1 & 3.2 \\
\hline & Absent & 30 & 96.8 \\
\hline
\end{tabular}




\begin{tabular}{|c|c|c|c|}
\hline $\mathbf{4}$ & Radiation & & \\
\hline & Present & 2 & 6.4 \\
\hline & Absent & 29 & 93.6 \\
\hline $\mathbf{5}$ & Genetic Factors & & \\
\hline & Present & 5 & 16.1 \\
\hline & Absent & 26 & 83.8 \\
\hline
\end{tabular}

Table 2. Risk Factors for Primary Lung Cancer among the Study Participants

The particulars regarding clinical complications of primary lung cancer are given in Table 3. SVC obstruction was present in 2 patients (6.4\%), while CNS metastasis was seen in 3 patients $(9.6 \%)$. Liver metastasis was seen in 1 patient $(3.2 \%)$, while bone (ribs and vertebral) metastasis was seen in 3 patients (9.6\%). Vocal cord palsy was seen in 3 patients $(9.6 \%)$.

\begin{tabular}{|c|c|c|c|}
\hline Sl. No. & $\begin{array}{c}\text { Clinical } \\
\text { Complications } \\
\end{array}$ & $\begin{array}{c}\begin{array}{c}\text { Frequency } \\
\mathrm{N}=31\end{array} \\
\end{array}$ & Percentage \\
\hline \multirow[t]{3}{*}{1} & SVC Obstruction & & \\
\hline & Present & 2 & 6.4 \\
\hline & Absent & 29 & 93.6 \\
\hline \multirow[t]{3}{*}{2} & CNS Metastasis & & \\
\hline & Present & 3 & 9.6 \\
\hline & Absent & 28 & 90.4 \\
\hline \multirow[t]{3}{*}{3} & Liver Metastasis & & \\
\hline & Present & 1 & 3.2 \\
\hline & Absent & 30 & 96.8 \\
\hline \multirow[t]{3}{*}{4} & Bone Metastasis & & \\
\hline & Present & 3 & 9.6 \\
\hline & Absent & 28 & 90.4 \\
\hline \multirow[t]{3}{*}{5} & Vocal Cord Palsy & & \\
\hline & Present & 3 & 9.6 \\
\hline & Absent & 28 & 90.4 \\
\hline & $\begin{array}{c}\text { Clinical Complic } \\
\text { among the }\end{array}$ & $\begin{array}{l}\text { of Prim } \\
\text { articipc }\end{array}$ & Cancer \\
\hline
\end{tabular}

The distribution of clinical symptoms according to the type of carcinoma is given in Table 4. Cough $(66.7 \%)$ and haemoptysis (83.3\%) were the predominant symptoms of squamous cell carcinoma, while chest pain $(50 \%)$ was the predominant symptom of adenocarcinoma.

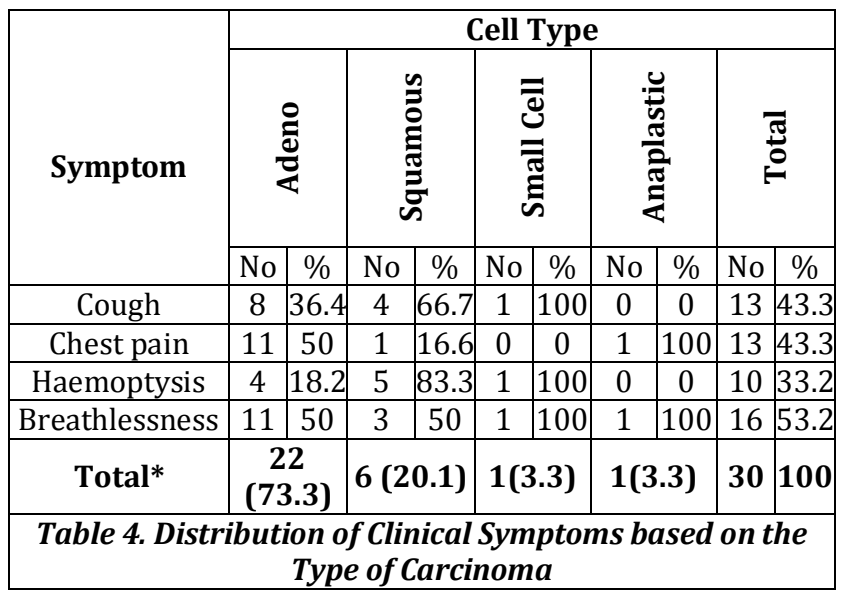

*Percentages will not total to 100.

\section{DISCUSSION}

Lung cancer is one of the commonest malignant neoplasm in India both in males and females, and the gender difference is narrowing. Complex circumstances like genetic predis- position, environmental exposure, lifestyle habits combine over a lifetime to initiate and promote tumour growth in the lung. In our study the mean age was 49 years, which was similar to the study conducted by Jindal SK and Behera D (5) where the mean age was 52 years.[6]

Most common pulmonary symptom in this study was breathlessness, 16 patients (51.61\%) followed by cough 13 patients $(41.94 \%)$ and chest pain 13 patients $(41.94 \%)$. Squamous cell carcinoma being the central type of malignancy presented with cough $(66.7 \%)$ and haemoptysis $(83.3 \%)$ as the predominant symptoms. Adenocarcinoma, being the peripheral type of malignancy, chest pain (50\%) was the predominant symptom. Breathlessness was present in more than $50 \%$ of the study population, which can be attributed to the later stage of the disease in most of the study population and to the pleural involvement.

Tobacco smoking is the most important risk factor for lung cancer. None of the patients in this study was a smoker. But exposure to environmental tobacco smoke was present in $45 \%$ of patients. Environmental Tobacco Smoke (ETS) is an important indoor as well as outdoor air pollutant that may be a contributing risk factor. Exposure to environmental tobacco smoke was present in 14 patients $(45.16 \%)$. This is less compared to the study done by T. Behera and T. Balamugesh, where the exposure was 53\%.[7]

Significant exposure to domestic biomass cooking fuels like wood, cow dung cake, agricultural waste, coal etc. was present in 12 patients (38.71\%). This is less compared to the study done by T. Behera and T. Balamugesh. Among 12 patients, 10 were adenocarcinoma. ${ }^{[7]}$

Exposure to occupational carcinogens like asbestos was present in 1 patient (3.23\%) and the cell type was adenocarcinoma. In the study conducted by De Vos Irvine and colleagues, the prevalence was 5.7\%.[8] Exposure to radiation was present in 2 patients $(6.45 \%)$. Of these 2 patients, one patient gave history of radiotherapy treatment for Hodgkin's Lymphoma 15 years back and another patient is residing in area of atomic power station for more than 25 years. Genetic predisposition to get cancer was present in 5 patients (16.13\%).

\section{CONCLUSION}

Environmental Tobacco Smoke and Biomass cooking fuel exposure constituted about $84 \%$ of risk factors identified in this study. In addition to the above risk factors, occupational pollutants and radiation have an additive effect in the background of genetic predisposition in the causation of Lung Cancer in females. Lung lesions in females in high-risk age group of 40 years and above should be investigated without gender bias thoroughly to rule out malignancy. This approach may result in diagnosing malignancy at an early stage. Primary lung malignancies are common only in smokers is proved as a misconception as evidenced by this study.

\section{Limitations}

- The number of cases studied was only 31 .

- Exact quantification of exposure to risk factors not possible. 


\section{REFERENCES}

[1] Ferlay J, Shin HR, Bray F, et al. GLOBOCAN 2008, Cancer Incidence and Mortality Worldwide: IARC Cancer Base No. 10 Lyon, France: International Agency for Research on Cancer 2010. http://globocan.iarc.fr

[2] National Cancer Institute, SEER Cancer Statistics Review 1975-2008. Lifetime Risk (Percent) of Being Diagnosed with Cancer by Site and Race/Ethnicity: Males, 17 SEER Areas, 2006-2008 (Table 1.15) and Females, 17 SEER Areas, 2006-2008 (Table 1.16). 2011.http://seer.cancer.gov/csr/1975_2008/results_ merged/topic_lifetime_risk_diagnosis.pdf.

[3] Howlader N, Noone AM, Krapcho M, et al. SEER Cancer Statistics Review, 1975-2009 (Vintage 2009 Populations). National Cancer Institute. Bethesda, MD. http://seer.cancer.gov/csr/1975_2009_pops09/
[4] International agency for research on cancer. World Health Organization Available from http://globocan.iarc.fr/Pages/fact_sheets_cancer.aspx

[5] Parkin DM, Bray F, Ferlay J, et al. Global cancer statistics, 2002. CA Cancer J Clin 2005;55(2):74-108.

[6] Jindal SK, Behera D. Clinical spectrum of primary lung cancer - review of Chandigarh experience of 10 years. Lung India 1990;8(2):94-8.

[7] Behera D, Balamugesh T. Indoor air pollution as a risk factor for lung cancer in woman. JAPI 2005;53:190-2.

[8] De Vos Irvine H, Lamont DW, Hole DJ, et al. Asbestos and lung cancer in Glasgow and the west of Scotland. Br Med J 1993;306(6891):1503-6. 